\title{
MODELING OF THE EFFECTIVE FUNCTIONING OF THE AGRICULTURAL LANDS MARKET IN UKRAINE
}

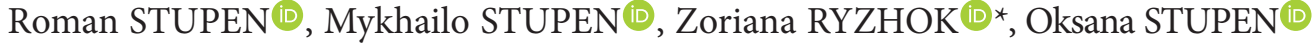 \\ Faculty of Land Organisation, Lviv National Agrarian University, Dublyany, Ukraine
}

Received 4 January 2019; accepted 18 September 2019

\begin{abstract}
The article deals with the main problems of creating the agricultural lands market in Ukraine due to the absence of the normative and legal support of its circulation, which should define the set of rights and restrictions of the implementation of this process. It is determined that the agricultural lands market is a social and economic complex that functions in accordance with market laws, national specificity, territorial scope and consists of a set of enterprises, establishments and representative offices, which are directly related to turnover of agricultural lands market. The main prerequisites for formation of effective functioning of the agricultural lands market are substantiated. Structural and logical scheme of this process implementation is constructed. Despite the ban on the purchase and sale of agricultural lands, the market value of land for private peasant farming has been calculated according to an expert assessment of a comparative methodological approach in determining the degree of similarity of objects using the Euclidean distance. The proposed method is appropriate to use in determining the market land value, regardless of its target use, by the degree of similarity of the objects of comparison according to the area, location, physical characteristics, functional characteristics and the availability of improvements, which allows to take into account its quantitative and qualitative characteristics.
\end{abstract}

Keywords: modeling, comparative approach, effectiveness, market, land plot, agriculture.

\section{Introduction}

In today's conditions of the market economy an agricultural land market is needed for the purpose of the sustainable development of the agrarian sector, as well as the creation of a balanced land use system (Stupen, \& Ryzhok, 2018). However, the successful formation, development as well as the efficient functioning of the agricultural lands market depend on many factors. The issue of its formation is very acute: on the one hand, this process is subconsciously perceived by the population negatively, and, on the other hand, it is necessary for the development and formation of Ukraine as a developed European state. Under these conditions, we are faced with the task of providing proposals for the functioning of an efficient land market that properly performs its main functions in the existing stereotypes in the society that hinder the development of the land market in Ukraine.

The significant contribution to the solution of theoretical, methodological and applied problems of the formation of the agricultural lands market was made by D. Dobriak (2015), A. Martyn (2011), L. Novakovskyi (2013),
M. Stupen (R. Stupen, M. Stupen, \& O. Stupen, 2018c), A. Tretiak (A. Tretiak, V. Tretiak, Kovalyshyn, \& N. Tretiak, 2016), M. Fedorov (2009) and others. However, the views on the problem solution of forming the agricultural lands market are different, up to the opposite ones. Some people consider that it is necessary to open a full land market with certain restrictions immediately. Others insist on a moratorium continuation and a phased market introduction. There is a group of scientists, which in general, require the removing of any restrictions on the purchase and sale of agricultural lands.

\section{Materials and methods}

The comparative approach is the most adapted to market requirements since it reflects its economic situation objectively (Stupen, Mykula, \& Radomskyi, 2012). However, it should be noted that the greatest difficulty in using this approach is the absence of a developed agricultural lands market in Ukraine, and, therefore, the data on the value of land plots according to expert assessment. Thus, we have disclosed the features of the method of similarity degree

*Corresponding author. E-mail: zoryana.rizhock@gmail.com 
of objects by using the Euclidean distance in determining the market value of agricultural lands.

The Euclidean distance approximates the distances between comparison objects, which are described by quantitative and qualitative features of the comparison elements. If it is necessary to quantify the weight of factor features or to align the scale of heterogeneous features, it is appropriate to weigh the distances, defined by the Euclidean distance:

$$
d_{i j}^{(w E)}=\sqrt{\sum_{k=1}^{p} w_{k}}\left(a_{i k}-a_{j k}\right)^{2},
$$

where $w_{k}$ - weight coefficients for $k$ feature under the condition that their sum is equal to one; $a_{i k}$ - meaning of $k$ factor feature of $i$ comparison object; $a_{j k}$ - the meaning of $k$ factor feature of $j$ comparison object.

The Euclidean distance is used to determine the degree of similarity of the evaluation objects, since the smaller the value of distance $d_{i j}$, then as to the selected features $i$ object is closer to $j$ comparison object. That is, the value $s_{i j}$, is the similarity degree of $i$ and $j$ object. This value is the inverse of the value between these objects:

$$
s_{i j}=\frac{1}{d_{i j}} .
$$

If one chooses objects for comparison, some of them will exceed the evaluation object as to the factor features, and the other part of them - concede it, then the value of the evaluation object can be determined by the formula:

$$
V_{0}=\sum_{i=1}^{n} w i \times P i,
$$

where $V_{0}$ - the market value of object evaluation; $P i-$ the price of sale of $i$ comparison object; $w i$ - weight coefficient, which reflects the probability that the value of evaluation object will be the same as the sale price of $i$ comparison object (Drapikovskyi, Ivanova, \& Tereshchenko, 2016):

$$
w_{i}=\frac{s_{o i}}{\sum_{i=1}^{n} s_{o i}} .
$$

\section{Results and discussions}

The introduction of the agricultural lands market should begin with the normative and legal support of its circulation, which in fact should define the set of rights and restrictions of the implementation of this process. These are restrictions such as limiting the range of market subjects, the preferential right to purchase. There is a conflict between land market participants in further reforming land relations because of these issues. Therefore, first of all, justification of the mechanism of effective functioning of the agricultural land market is necessary in order to reconcile the interests of land relations subjects.

The agricultural lands market is a mechanism for realizing economic relations between sellers and buyers in relation to the sale and purchase of a specific type of commodity - agricultural lands. In the broadest sense, the agricultural lands market is a social and economic complex that functions in accordance with market laws, national specificity, and territorial scope. To add more, it consists of enterprises, institutions, offices directly related to the market turnover of agricultural lands.

Moreover, the main preconditions for the formation of an efficient functioning of the agricultural lands market is the development of a legal and regulatory framework for strengthening and realization of the right of private ownership on land; creation of competitive forms of agrarian production organization (personal peasant, farmer, cooperative and joint stock companies); providing citizens with equal opportunities for access to land resources; provision of effective antimonopoly measures for the regulation of the agricultural land market; development of the institutional environment that regulates the mechanism of interaction of economic subjects involved in land relations (Hnatkovych, 2014; Zaiats, 2012).

However, the attention of state policy in the agrarian sector on accelerated and inadequately motivated privatization of land and property caused the destruction of large commodity agricultural production, which has not been effective in the formation of new productive forms (R. Stupen, M. Stupen, \& O. Stupen, 2018b). The area of agricultural lands, used in agricultural production, has decreased by almost 8 million hectares for 25 years of the land reform in Ukraine. There has been an unacceptable division of the structure of agrarian production (N. Stupen, M. Stupen, \& O. Stupen, 2018a). There has been no effective system of functioning of the agricultural lands market, and therefore numerous prohibitions and restrictions on their circulation have been introduced. As a result, civil and legal land agreements are not transparent and controlled, and its participants, the state and local self-government suffer economic losses. In general, as we see the experience of establishing a land sale and purchase ban is not an ineffective measure (Sakh, Pavlychenko, Polonskyi, \& Ursu, 2007).

The legislation of Ukraine set a moratorium on the alienation of agricultural lands (Law of Ukraine No. 276814 (Verhovna Rada Ukraini, 2001b)). However, there are no prohibitions on the sale and purchase of land for private peasant farming located within settlements in residential buildings that are actually used for gardening and horticulture. As a rule, they are alienated together with objects of residential real estate. They have market value and can be freely traded in the secondary land market.

It is vital to stress that the legal regulation of land valuation is carried out in accordance with the Land Code of Ukraine (Law of Ukraine No. 2768-14 (Verhovna Rada Ukraini, 2001b)), the Laws of Ukraine "On State Land Cadastre" (Law of Ukraine No. 3613-VI (Verhovna Rada Ukraini, 2011)), "On Land Valuation" (Law of Ukraine No. 1378-IV (Verhovna Rada Ukraini, 2003)), “On Evaluation of Property, Property Rights and Professional Appraisal Activity in Ukraine" (Law of Ukraine No. 2658-III (Verhovna Rada Ukraini, 2001a)), the Order of the State Committee of Ukraine for Land Resources "On the Procedure 


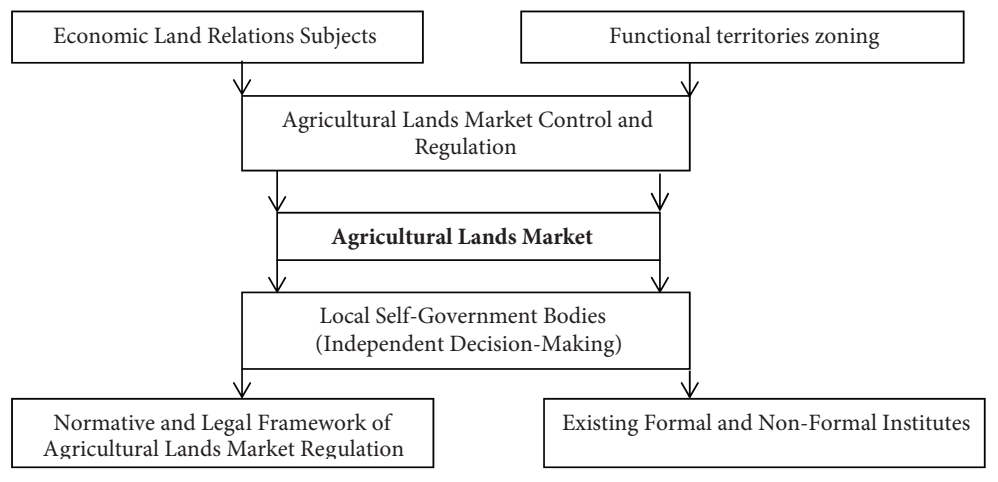

Figure 1. The structural and logical scheme of effective functioning of the agricultural lands market

of Conducting an Expert Monetary Evaluation of Land Plots" (Law of Ukraine No. 2 (Derzhavnij komitet Ukraini po zemel'nih resursah, 2003)).

As a result of the research the structural and logical scheme of effective functioning of the agricultural lands market is proposed in Figure 1.

We have the task of determining the market value of $100 \mathrm{~m}^{2}$ of agricultural land plot for the conducting a private peasant business (Dubliany OLX, 2018). There are not land improvements on the land plot of the regular shape. Moreover, accessibility to that plot is organized from the road of state importance. In fact, we have detected the recent sales of similar land plots, located in Zhovkva district of Lviv region, at a distance of $15 \mathrm{~km}$ from the city of Lviv (Table 1) for the calculation of expert assessment by a comparative methodological approach in determining the similarity degree of objects using the Euclidean distance (Drapikovskyi, Ivanova, \& Krumelis, 2011).

Then we make qualitative features formal, indicating the physical characteristics (the shape of the land) "regular" as 1, and "irregular" - 0; functional features (use of adjacent territory) - "accessibility to the road of state importance" as 2, "accessibility to the road of district significance" - 1, "no" - 0 ; the existence of improvements on the land plot - "yes" as 1, "no" - 0 and we will create a transformed state table (Table 2).

Table 1 . The table of state

\begin{tabular}{|c|c|c|c|c|c|c|}
\hline \multirow[b]{2}{*}{ Objects } & \multirow[b]{2}{*}{$\begin{array}{c}\text { Sale } \\
\text { Value, } \\
\text { USD }\end{array}$} & \multicolumn{5}{|c|}{ Comparison Elements } \\
\hline & & Area, $\mathrm{m}^{2}$ & $\begin{array}{l}\text { Location (distance } \\
\text { from the city of } \\
\text { Lviv, } \mathrm{km} \text { ) }\end{array}$ & $\begin{array}{c}\text { Physical } \\
\text { Features (Land } \\
\text { Plot Shape) }\end{array}$ & $\begin{array}{c}\text { Functional Features } \\
\text { (the Use of Adjacent Territory) }\end{array}$ & $\begin{array}{l}\text { The Existence of } \\
\text { Improvements on } \\
\text { Land Plot }\end{array}$ \\
\hline $\begin{array}{l}\text { Evaluation } \\
\text { Objects }\end{array}$ & & 100 & 3 & regular & $\begin{array}{l}\text { accessibility to the road of state } \\
\text { importance }\end{array}$ & no \\
\hline $\begin{array}{l}\text { Comparison } \\
\text { Object } 1\end{array}$ & 650 & 200 & 10 & irregular & $\begin{array}{l}\text { accessibility to the road of district } \\
\text { importance }\end{array}$ & yes \\
\hline $\begin{array}{l}\text { Comparison } \\
\text { Object } 2\end{array}$ & 600 & 500 & 10 & irregular & $\begin{array}{l}\text { accessibility to the road of district } \\
\text { importance }\end{array}$ & no \\
\hline $\begin{array}{l}\text { Comparison } \\
\text { Object } 3\end{array}$ & 550 & 100 & 15 & irregular & no & no \\
\hline $\begin{array}{l}\text { Comparison } \\
\text { Object } 4\end{array}$ & 700 & 150 & 5 & regular & $\begin{array}{l}\text { accessibility to the road of district } \\
\text { importance }\end{array}$ & no \\
\hline $\begin{array}{l}\text { Comparison } \\
\text { Object } 5\end{array}$ & 750 & 100 & 2 & regular & $\begin{array}{l}\text { accessibility to the road of state } \\
\text { importance }\end{array}$ & yes \\
\hline
\end{tabular}

Table 2. Transformed state table

\begin{tabular}{|l|c|c|c|c|c|}
\hline \multirow{2}{*}{ Objects } & \multicolumn{5}{|c|}{ Comparison Elements } \\
\cline { 2 - 6 } & Area, $\mathrm{m}^{2}$ & $\begin{array}{c}\text { Location (distance } \\
\text { from the city of } \\
\text { Lviv, km) }\end{array}$ & $\begin{array}{c}\text { Physical Features } \\
\text { (Land Plot Shape) }\end{array}$ & $\begin{array}{c}\text { Functional Features } \\
\text { (the Use of Adjacent } \\
\text { Territory) }\end{array}$ & $\begin{array}{c}\text { The Existence of } \\
\text { Improvements on } \\
\text { Land Plot }\end{array}$ \\
\hline Evaluation Objects & 100 & 3 & 1 & 2 & 0 \\
\hline Comparison Object 1 & 200 & 10 & 0 & 1 & 1 \\
\hline Comparison Object 2 & 500 & 10 & 0 & 0 & 0 \\
\hline Comparison Object 3 & 100 & 15 & 1 & 1 & 0 \\
\hline Comparison Object 4 & 150 & 5 & 1 & & 2 \\
\hline Comparison Object 5 & 100 & 2 & 0 & \\
\hline
\end{tabular}


We convert Table 2 into the comparison table, subtracting from the value of each element of comparison that characterizes the evaluation object, the value of the same element that characterizes the comparison object (Table 3).

Taking into account that the elements of comparison have had different and incomparable units of measure (square meters, kilometers, land plot shape, use of adjacent territory and the existence of improvements), we will carry out the valuation of the comparison elements.

For the fulfillment of this task, we calculate the length of each column vector, which characterizes the difference between comparison objects from an object, which is evaluated by the $j$ factor as the square root of the sum of squares of all elements of the corresponding column (Table 4).

Then we will replace the absolute values of the comparison elements on the normalized ones in the comparison table (Table 5).

We calculate the distance of comparison objects from the evaluation object by the number of comparison elements using the Euclidean distance, having previously determined the normalized values of the comparison elements in the square (Table 6).

Table 3. Comparison table

\begin{tabular}{|l|c|c|c|c|c|}
\hline \multirow{2}{*}{ Objects } & \multicolumn{5}{|c|}{ Comparison Elements } \\
\cline { 2 - 6 } & Area, $\mathrm{m}^{2}$ & $\begin{array}{c}\text { Location } \\
\text { (distance from the } \\
\text { city of Lviv, km) }\end{array}$ & $\begin{array}{c}\text { Physical Features } \\
\text { (Land Plot Shape) }\end{array}$ & $\begin{array}{c}\text { Functional Features } \\
\text { (the Use of Adjacent } \\
\text { Territory) }\end{array}$ & $\begin{array}{c}\text { The Existence of } \\
\text { Improvements on } \\
\text { Land Plot }\end{array}$ \\
\hline Comparison Object 1 & -100 & -7 & 1 & 1 & -1 \\
\hline Comparison Object 2 & -400 & -7 & 1 & 1 & 0 \\
\hline Comparison Object 3 & 0 & -12 & 0 & 1 & 0 \\
\hline Comparison Object 4 & -50 & -2 & 0 & 0 & -1 \\
\hline Comparison Object 5 & 0 & 1 & & & -1 \\
\hline
\end{tabular}

Table 4. Calculation of the base of the valuation of the comparison elements

\begin{tabular}{|c|c|c|c|c|c|}
\hline \multirow[b]{2}{*}{ Objects } & \multicolumn{5}{|c|}{ Comparison Elements } \\
\hline & Area, $\mathrm{m}^{2}$ & $\begin{array}{l}\text { Location (distance } \\
\text { from the city of } \\
\text { Lviv, km) }\end{array}$ & $\begin{array}{l}\text { Physical Features } \\
\text { (Land Plot Shape) }\end{array}$ & $\begin{array}{c}\text { Functional Features } \\
\text { (the Use of Adjacent } \\
\text { Territory) }\end{array}$ & $\begin{array}{c}\text { The Existence of } \\
\text { Improvements on } \\
\text { Land Plot }\end{array}$ \\
\hline Comparison Object 1 & -100 & -7 & 1 & 1 & -1 \\
\hline Comparison Object 2 & -400 & -7 & 1 & 1 & 0 \\
\hline Comparison Object 3 & 0 & -12 & 1 & 2 & 0 \\
\hline Comparison Object 4 & -50 & -2 & 0 & 1 & 0 \\
\hline Comparison Object 5 & 0 & 1 & 0 & 0 & -1 \\
\hline$\sum_{i=1}^{n}(\Delta a i j)^{2}$ & 172500 & 247 & 3 & 7 & 2 \\
\hline$\sqrt{\sum_{i=1}^{n}(\Delta a i j)^{2}}$ & 415.331 & 15.716 & 1.732 & 2.646 & 1.414 \\
\hline
\end{tabular}

Table 5. Transformed state table

\begin{tabular}{|l|c|c|c|c|c|}
\hline \multirow{2}{*}{ Objects } & \multicolumn{5}{|c|}{ Comparison Elements } \\
\cline { 2 - 6 } & Area, $\mathrm{m}^{2}$ & $\begin{array}{c}\text { Location (distance } \\
\text { from the city of } \\
\text { Lviv, km) }\end{array}$ & $\begin{array}{c}\text { Physical Features } \\
\text { (Land Plot Shape) }\end{array}$ & $\begin{array}{c}\text { Functional Features } \\
\text { (the Use of Adjacent } \\
\text { Territory) }\end{array}$ & $\begin{array}{c}\text { The Existence of } \\
\text { Improvements on } \\
\text { Land Plot }\end{array}$ \\
\hline Comparison Object 1 & -0.241 & -0.445 & 0.577 & 0.378 & -0.707 \\
\hline Comparison Object 2 & -0.963 & -0.445 & 0.577 & 0.378 & 0.000 \\
\hline Comparison Object 3 & 0.000 & -0.764 & 0.577 & 0.756 & 0.000 \\
\hline Comparison Object 4 & -0.120 & -0.127 & 0.000 & 0.378 & 0.000 \\
\hline Comparison Object 5 & 0.000 & 0.064 & 0.000 & 0.000 & -0.707 \\
\hline
\end{tabular}


Table 6. The distance of comparison objects from the evaluation object

\begin{tabular}{|l|c|c|c|c|c|}
\hline \multirow{2}{*}{ Comparison Elements } & \multicolumn{4}{c|}{ Comparison Objects } \\
\cline { 2 - 6 } & 1 & 2 & 3 & 4 \\
\hline Area, $\mathrm{m}^{2}$ & -0.241 & -0.963 & 0.000 & -0.120 & 0.000 \\
\hline Location (distance from the city of Lviv, km) & -0.445 & -0.445 & -0.764 & -0.127 & 0.064 \\
\hline Physical Features (Land Plot Shape) & 0.577 & 0.577 & 0.577 & 0.000 & 0.000 \\
\hline Functional Features (the Use of Adjacent Territory) & 0.378 & 0.378 & 0.756 & 0.378 & 0.000 \\
\hline The Existence of Improvements on Land Plot & -0.707 & 0.000 & 0.000 & 0.000 & -0.707 \\
\hline$\sum_{i=1}^{n}(\Delta a i j)^{2}$ & 1.735 & 0.893 & 1.488 & 0.378 \\
\hline Distance doi $=\sqrt{\sum_{i=1}^{n}\left(\Delta a j^{*}\right)^{2}}$ & & & & 0.504 \\
\hline
\end{tabular}

Table 7. Calculation table of value determination of object evaluation

\begin{tabular}{|c|c|c|c|c|c|}
\hline Objects & Distance, $d o i$ & $\begin{array}{l}\text { Similarity Degree, } \\
\qquad s_{o i}=\frac{1}{d o i}\end{array}$ & $\begin{array}{l}\text { The Weight of } \\
\text { Similarity Degree, } \\
\qquad w_{i}=\frac{s_{o i}}{\sum_{i=1}^{n} s_{o i}}\end{array}$ & Sale Value, USD, $P_{i}$ & $w_{i} \times P_{i}$ \\
\hline Comparison Object 1 & 1.317 & 0.759 & 0.134 & 650 & 87.10 \\
\hline Comparison Object 2 & 0.945 & 1.058 & 0.187 & 600 & 112.20 \\
\hline Comparison Object 3 & 1.22 & 0.820 & 0.145 & 550 & 79.75 \\
\hline Comparison Object 4 & 0.615 & 1.626 & 0.287 & 700 & 200.90 \\
\hline \multirow[t]{2}{*}{ Comparison Object 5} & 0.710 & 1.408 & 0.248 & 750 & 186.00 \\
\hline & $\sum_{i=1}^{n} s_{o i}$ & 5.672 & 1 & $\begin{array}{l}\text { Value of Evaluation } \\
\text { Object, } V_{0}=\sum_{i=1}^{n} w i \times P i\end{array}$ & 665.95 \\
\hline
\end{tabular}

As a result, we will determine the value of the evaluation object as a function of the sale price of the comparison objects and the degree of their similarity to the object of evaluation (Table 7).

According to calculation, the expert assessment of $100 \mathrm{~m}^{2}$ of agricultural land plot for personal peasant business, located in Zhovkva district of Lviv region for a comparative methodological approach in determining the degree of similarity of objects using the Euclidean distance is 665.95 USD in November 2018.

In addition, after lifting the moratorium on the turnover of agricultural lands, our proposed method for calculating the market value of land plot for private peasant business can be applied regardless of the use of lands.

\section{Conclusions}

In general, the adoption of a number of legislative acts, taking into account the interests of local communities, will create the legal preconditions for the introduction of agricultural lands market, which will provide for limited state regulation of the process of alienation of real rights on agricultural lands by owners, while minimizing its potential negative social and economic consequences.

To conclude with, according to an expert assessment, using a comparative methodological approach in determining the similarity degree of objects using the Euclidean distance after lifting the moratorium on the circulation of agricultural lands, we have proposed to determine the market value of land plot for private peasant business. The corresponding calculations were made on the example of a land plot located in Zhovkva district of Lviv region on the similarity degree of the objects of comparison according to the area, location, physical characteristics of the land plot, functional features, the existence of improvements on the land plot and is 665.95 USD per $100 \mathrm{~m}^{2}$.

\section{References}

Derzhavnij komitet Ukraini po zemel'nih resursah. (2003). Order of the State Committee of Ukraine for Land Resources from January 9, 2003. No. 2. On the Procedure of Conducting an Expert Monetary Evaluation of Land Plots. Retrieved from http://zakon3.rada.gov.ua/laws/show/z0396-03 
Dobriak, D. (2015). The current state of land reform and prospects of land relations in Ukraine. Land Management Herald, $4,2-4$.

Drapikovskyi, O., Ivanova, I., \& Krumelis, Y. (2011). Real estate valuation: Manual. Kyiiv: SIC Group Ukraine.

Drapikovskyi, O., Ivanova, I., \& Tereshchenko, N. (2016). Methods and models of real estate valuation: Manual. Kyiiv: Vipol.

Dubliany OLX. (2018). Land Sale. Retrieved from https://www. olx.ua/uk/nedvizhimost/zemlya/prodazha-zemli/zemlyaselskohozyaystvennogo-naznacheniya/dublyany/

Fedorov, M. (2009). Transformation of land relations as to market conditions: Report. Economics of Agro-Industrial Complex, 3, 4-18.

Hnatkovych, O. (2014). Ecological and economic aspects of realization of market land relations in agriculture. Scientific Notes of Ostroh Academy National University, "Economics" Series: Scientific Journal, 26, 28-32.

Martyn, A. (2011). Regulation of the land market in Ukraine: Monograph. Kyiiv: Agrar Media Group.

Novakovskyi, L. (2013). Modern problems of land relations regulation in Ukraine. Land Management Herald, 6, 2-6.

Sakh, D., Pavlychenko, P., Polonskyi, M., \& Ursu, O. (2007). Decentralization and effective local self-government: A manual for officials of local and regional authorities and local government development specialists. Kyiiv: United Nations Development Program/Municipal Governance and Sustainable Development Programme.

Stupen, M., Mykula, O., \& Radomskyi, S. (2012). Lands Valuation: Manual. Lviv: Liha-Pres.

Stupen, N., Stupen, M., \& Stupen, O. (2018a). Electronic agricultural maps formation on the basis of GIS and earth remote sensing. Scientific Papers Series "Management, Economic Engineering in Agriculture and Rural Development", 18(4), 347-353.
Stupen, R., \& Ryzhok, Z. (2018). Methodological approaches on the effective land resources use in the regions of Ukraine. Scientific Papers Series "Management, Economic Engineering in Agriculture and Rural Development", 18(4), 353-359.

Stupen, R., Stupen, M., \& Stupen O. (2018b). Formation of energy resources potential of rural territories. In Engineering for Rural Development: 17th International Scientific Conference (pp. 1639-1643). Latvia. https://doi.org/10.22616/ERDev2018.17.N038

Stupen, R., Stupen, M., \& Stupen, O. (2018c). Prospects of the land - rental relations development in agriculture of Ukraine. Scientific Papers Series "Management, Economic Engineering in Agriculture and Rural Development", 18(3), 441-448.

Tretiak, A., Tretiak, V., Kovalyshyn, O., \& Tretiak, N. (2016). The state and problems of methodological provision of agricultural lands valuation in Ukraine. Balanced Nature Use, 2, 113-117.

Verhovna Rada Ukraini. (2001a). Law of Ukraine from July 12, 2001. No. 2658-III. On Evaluation of Property, Property Rights and Professional Appraisal Activity in Ukraine. Retrieved from http://zakon2.rada.gov.ua/laws/show/2658-14

Verhovna Rada Ukraini. (2001b). Law of Ukraine from October 25, 2001. No. 2768-14. Land Code of Ukraine. Retrieved from http://zakon5.rada.gov.ua/laws/show/2768-14

Verhovna Rada Ukraini. (2003). Law of Ukraine from December 11, 2003. No. 1378-IV. On Land Valuation. Retrieved from http://zakon2.rada.gov.ua/laws/show/1378-15

Verhovna Rada Ukraini. (2011). Law of Ukraine from July 7, 2011. No. 3613-VI. On State Land Cadastre. Retrieved from http://zakon2.rada.gov.ua/laws/show/3613-17

Zaiats, V. (2012). The development of agricultural lands market: Monograph. Kyiiv: National Scientific Center "Institute of Agrarian Economics". 